\title{
Autoimmune Encephalitis in the Intensive Care Unit
}

\author{
Luisa A. Diaz-Arias, Carlos A. Pardo, and John C. Probasco
}

\section{Introduction}

Autoimmune encephalitis, a rapid, progressive encephalopathy that is secondary to an autoimmune response directed against the brain, is associated with significant morbidity, and often requires evaluation and treatment in the ICU not only for the underlying inflammatory response but also for its medical and neurological sequelae. In this chapter, we will discuss the epidemiology, clinical presentation, diagnostic approaches, and treatment options for autoimmune encephalitis as well as its sequelae, with particular focus on management and triage issues encountered by the intensivist.

\section{Definition}

Encephalitis is defined as neurologic dysfunction due to inflammation of the brain with the cerebral cortex or deep gray matter nuclei frequently involved. Infectious encephalitides have historically been the most common; however, autoimmune encephalitides have become increasingly recognized and described $[1,2]$.

Autoimmune encephalitides include not only those syndromes due to a primary autoimmune response but also those that are paraneoplastic. Similar to other paraneoplastic neurological syndromes, paraneoplastic autoimmune encephalitis results when systemic immune responses to peptide antigens of the tumor respond to similar to peptides found in the brain [3, 4]. Paraneoplastic autoimmune encephalitis occurs remotely from a known cancer or metastasis and can precede the detection of an associated cancer or cancer recurrence by years [3].

Since the original description of paraneoplastic autoimmune encephalitis, and particularly over the past two

L. A. Diaz-Arias · C. A. Pardo · J. C. Probasco ( $\triangle)$

Department of Neurology, Johns Hopkins University School of Medicine, Baltimore, MD, USA

e-mail: ldiazar1@jhmi.edu; cpardov1@jhmi.edu; jprobas1@jhmi.edu decades, autoimmune encephalitides have been identified and described in the absence of cancer. These primary autoimmune encephalitis syndromes are typically the result of immune responses directed against cell surface proteins (e.g., neurotransmitter receptors) [5]. For the purposes of this chapter, we will consider both paraneoplastic and nonparaneoplastic autoimmune encephalitis together.

\section{Epidemiology}

Autoimmune encephalitis is seen in a broad age range but most commonly affects young people. The annual incidence of encephalitis is up to 12.6 per 100,000 individuals $[1,6,7], 20-30 \%$ of whom have an underlying autoimmune etiology $[6,7]$. One recent population-based study found the prevalence of autoimmune encephalitis as 13.7 per 1000,000 individuals, comparable to all infectious encephalitides [2]. These observations may still be underestimates if we consider that as many as $50 \%$ of encephalitis patients have an unknown etiology $[6,7]$ and that the paraclinical findings associated with various autoimmune encephalitides included in recent consensus clinical criteria may be transient or of varied sensitivity [5]. Interestingly, new immune activating therapies introduced for oncological purposes are influencing the incidence of autoimmune encephalitis [8]. Although the clinical profile of encephalitic syndromes may suggest autoimmune causes, some clinical presentations may not immediately raise concerns for autoimmune encephalitis. For instance, new onset refractory status epilepticus (which may occur without cognitive or behavioral changes) may appear to be solely epileptic; however, over one third of these cases are found to be due to autoimmune encephalitis [9]. With improved identification of autoantibodies through refined testing practices and assay advances, the development and application of consensus clinical criteria, and the description of novel autoantibody-associated autoimmune encephalitis 
syndromes over the past decade, the incidence of autoimmune encephalitis is anticipated to continue to rise $[1,2]$.

Patients with autoimmune encephalitis commonly require care in an ICU $[10,11]$. In one retrospective series at a tertiary referral center, $55 \%$ of patients meeting consensus clinical criteria for possible autoimmune encephalitis were admitted to the neurocritical care unit [10]. Patients particularly at risk for ICU admission are those who had a longer duration of symptoms before hospitalization and anemia, likely a marker of systemic inflammation [12]. Seizures (including status epilepticus), subacute cognitive decline, and respiratory failure are the most common indications for neurocritical care [10-13]. Almost $70 \%$ of patients with autoimmune encephalitis have critical care needs at some point during their initial hospital stay [14], with ICU stays greater than 4 days observed in $44 \%$ of patients in one series [13]. As discussed below, patients with autoimmune encephalitis are at risk for a variety of neurological and medical complications, with a mortality rate up to $40 \%$ in the ICU $[11,13]$.

\section{Clinical Presentation}

In general, the clinical presentation of autoimmune encephalitis is rapid in both onset and progression. Consensus clinical criteria were recently developed to promote the early identification of patients with autoimmune encephalitis and facilitate early initiation of immunosuppressive therapy [5]. These criteria require a subacute and progressive encephalopathy, typically over the course of days to weeks (as opposed to the months or years commonly seen in those with neurodegenerative disorders) [5]. Prodromal symptoms, such as headache and nonspecific respiratory or gastrointestinal illnesses, may precede the development of encephalopathy [15-17].

This characteristic subacute clinical presentation includes progressive deficits in working memory, altered mental status (i.e., change in level of consciousness, lethargy, and/or personality change), and/or psychiatric symptoms over a course of less than 3 months [5]. These symptoms may be accompanied by other neurological symptoms or examination findings suggesting involvement of the central nervous system [5]. Some symptoms and findings may provide clues for specific autoimmune encephalitis syndromes, such as faciobrachial dystonic seizures, neuromyotonia, and orofacial dyskinesia with newonset psychosis being linked to the specific antibodies anti-leucine-rich glioma-inactivated 1 (anti-LGI1), anticontactin-associated protein 2 (anti-CASPR2), and anti-Nmethyl-D-aspartate receptor (anti-NMDAR) antibodies, respectively (Table 17.1) [18-20].

The clinical presentations of anti-NMDAR encephalitis and anti-LGI1 encephalitis deserve particular mention, as they are the most commonly described autoimmune encephalitides (Tables 17.2 and 17.3). This is likely the product of the recent detailed descriptions of these respective syndromes as well as the specificity of the respective antibodies to each syndrome. The clinical presentation of anti-NMDAR encephalitis is characterized by a viral illness-like prodrome of fever and/or headache followed over the course of days to weeks by personality changes (e.g., agitation, paranoia), short-term memory loss, and abnormal movements (e.g., ballismus, catatonia, choreoathetosis, dyskinesias, and/or dystonia) [21]. Patients can subsequently progress to develop generalized or partial-onset seizures and status epilepticus, depressed levels of consciousness, central hypoventilation, and dysautonomia. The majority of patients are female and in the second to third decades of life. With that said, the age range of cases extends from early childhood through the late elderly years, with anti-NMDAR encephalitis manifesting among males more commonly in the first through second decades [20]. Across all age groups, behavioral change is the most common first symptom, while seizures are prevalent [20]. This may be why anti-NMDAR encephalitis is frequently initially misdiagnosed as a psychiatric disorder [22, 23]. Movement disorders are common among patients less than 12 years in age, less so among those who are older [20]. Only $38 \%$ of patients are found to have an underlying malignancy at the time of initial presentation, most often an ovarian teratoma (94\%) although a variety of other malignancies have been reported such as extraovarian teratomas and cancers of the lung and breast [20].

Anti-LGI1 encephalitis accounts for $40 \%$ of patients seropositive for antibodies directed against the voltage-gated potassium channel (anti-VGKC) complex. Of the remaining patients, $10 \%$ have anti-CASPR2 antibodies and $50 \%$ are seronegative for both anti-LGI1 and anti-CASPR. The "double negative" anti-VGKC seropositive population is heterogeneous in terms of syndromes, cancer association, and response to immunosuppression, possibly reflecting immune responses to other proteins associated with the VGKC complex that have yet to be characterized, limiting its value as a specific marker of autoimmune neuroinflammation [24].

Patients with anti-LGI1 encephalitis most commonly present in their sixth to eighth decade with limbic encephalitis. Anti-LGI1 encephalitis is characterized by shortterm memory loss, seizures, and psychiatric symptoms, with evidence of a combination of medial temporal lobe inflammation, temporal lobe epilepsy or dysfunction, or intrathecal inflammation. A large subset of patients (13\%) present without evidence of brain inflammation by magnetic resonance imaging (MRI) or cerebrospinal fluid (CSF) analysis [25]. Faciobrachial dystonic seizures (FBDS) have been described preceding the development of short-term memory loss and encephalopathy suggestive of limbic encephalitis by weeks to months in 
Table 17.1 Autoantibodies in autoimmune encephalitis

\begin{tabular}{|c|c|c|c|c|c|}
\hline Antibody & $\begin{array}{l}\text { Antigen } \\
\text { class }\end{array}$ & $\begin{array}{l}\text { Syndromes and associated } \\
\text { neurological findings }\end{array}$ & $\begin{array}{l}\text { Frequency } \\
\text { of cancer }\end{array}$ & Main cancer type & Response to immunotherapy \\
\hline \multicolumn{6}{|c|}{ Limbic encephalitides } \\
\hline $\begin{array}{l}\text { AMPA receptor } \\
{[68]}\end{array}$ & $\begin{array}{l}\text { Synaptic } \\
\text { receptor }\end{array}$ & $\begin{array}{l}\text { Limbic encephalitis, epilepsy, } \\
\text { nystagmus }\end{array}$ & $65 \%$ & $\begin{array}{l}\text { Thymoma, small-cell } \\
\text { lung carcinoma }\end{array}$ & $\begin{array}{l}71 \% \text { with partial }(N=10) \text { or good } \\
\text { response }(N=5) \text { after treatment with } \\
\text { immunotherapy and oncologic therapy } \\
\text { as appropriate }(N=21)\end{array}$ \\
\hline Amphiphysin [69] & Intracellular & $\begin{array}{l}\text { Limbic encephalitis, } \\
\text { stiff-person syndrome, more } \\
\text { general encephalitis, subacute } \\
\text { cerebellar degeneration, } \\
\text { myelopathy, subacute sensory } \\
\text { neuronopathy, peripheral } \\
\text { neuropathy }\end{array}$ & $79 \%$ & $\begin{array}{l}\text { Small-cell lung } \\
\text { carcinoma, breast, } \\
\text { thymoma }\end{array}$ & $\begin{array}{l}\text { Among patients with various } \\
\text { syndrome who were anti-amphiphysin } \\
\text { seropositive, various first-line } \\
\text { therapies used with } 80 \% \text { improving } \\
\text { who received corticosteroids }(N=5) \text {, } \\
50 \% \text { of those who received IVIG } \\
(N=4), \text { none with plasmapheresis } \\
(N=4) .60 \% \text { treated with oncologic } \\
\text { therapy improved }(N=20)\end{array}$ \\
\hline $\begin{array}{l}\text { CASPR2 } \\
\text { (contactin- } \\
\text { associated protein } \\
\text { 2) [19] }\end{array}$ & Cell surface & $\begin{array}{l}\text { Limbic encephalitis, Morvan } \\
\text { syndrome, neuromyotonia }\end{array}$ & $20-50 \%$ & Thymoma & $\begin{array}{l}52 \% \text { with partial and } 39 \% \text { with } \\
\text { complete recovery after treatment with } \\
\text { various combinations of first-line } \\
\text { immunotherapy }(N=23)\end{array}$ \\
\hline $\begin{array}{l}\text { CV2/CRMP } \\
\text { (collapsing } \\
\text { response mediator } \\
\text { protein) } 5[70-72]\end{array}$ & Intracellular & $\begin{array}{l}\text { Limbic encephalitis, more } \\
\text { general encephalitis, chorea, } \\
\text { subacute cerebellar } \\
\text { degeneration, cranial } \\
\text { neuropathies, uveitis, optic } \\
\text { neuritis, retinopathy, } \\
\text { myelopathy, subacute sensory } \\
\text { neuronopathy, autonomic } \\
\text { neuropathy, peripheral } \\
\text { neuropathy }\end{array}$ & $87 \%$ & $\begin{array}{l}\text { Small-cell lung } \\
\text { carcinoma, } \\
\text { thymoma, uterine } \\
\text { sarcoma, prostate } \\
\text { small cell carcinoma }\end{array}$ & $\begin{array}{l}\text { Limited to case series of various } \\
\text { syndromes (mostly movement } \\
\text { disorders). Range of response to } \\
\text { immunotherapy } 13-50 \% \text {, primarily } \\
\text { intravenous methylprednisolone. The } \\
\text { primary focus of care is on } \\
\text { oncological therapy }\end{array}$ \\
\hline $\begin{array}{l}\mathrm{GABA}_{\mathrm{B}} \text { receptor } \\
{[73]}\end{array}$ & $\begin{array}{l}\text { Synaptic } \\
\text { receptor }\end{array}$ & $\begin{array}{l}\text { Limbic encephalitis, epilepsy, } \\
\text { cerebellar ataxia }\end{array}$ & $50 \%$ & $\begin{array}{l}\text { Small-cell lung } \\
\text { carcinoma }\end{array}$ & $\begin{array}{l}33 \% \text { with a complete response and } \\
40 \% \text { with partial response to } \\
\text { immunotherapy alone; } 13 \% \text { with a } \\
\text { complete response and } 13 \% \text { with } \\
\text { partial response to immunotherapy } \\
\text { and oncological therapy }(13 \% \text {; } \\
N=15)\end{array}$ \\
\hline $\begin{array}{l}\text { GAD } 65(65 \mathrm{kDa} \\
\text { glutamic acid } \\
\text { decarboxylase }) \\
{[74]}\end{array}$ & Intracellular & $\begin{array}{l}\text { Limbic encephalitis, } \\
\text { stiff-person syndrome, } \\
\text { cerebellar ataxia, autoimmune } \\
\text { epilepsy, brainstem and more } \\
\text { general encephalitis, } \\
\text { myelopathy, large fiber } \\
\text { peripheral neuropathy, } \\
\text { autonomic neuropathy }\end{array}$ & $15 \%$ & $\begin{array}{l}\text { Small-cell or } \\
\text { non-small-cell lung } \\
\text { carcinoma, thymoma } \\
\text { or thymic carcinoma, } \\
\text { testicular seminoma, } \\
\text { thyroid neoplasia, } \\
\text { breast } \\
\text { adenocarcinoma, } \\
\text { gastrointestinal } \\
\text { carcinomas, renal } \\
\text { cancer, lymphoma, } \\
\text { myeloma }\end{array}$ & $\begin{array}{l}\text { Across all neurological phenotypes of } \\
\text { GAD65 autoimmunity, approximately } \\
50 \% \text { of patients improve with } \\
\text { immunotherapy }\end{array}$ \\
\hline $\mathrm{Hu}$ (ANNA1) [75] & Intracellular & $\begin{array}{l}\text { Limbic encephalitis, } \\
\text { brainstem encephalitis, more } \\
\text { general encephalitis, subacute } \\
\text { cerebellar degeneration, } \\
\text { myelitis, sensory } \\
\text { neuronopathy, autonomic } \\
\text { neuropathy, peripheral } \\
\text { neuropathy }\end{array}$ & $84 \%$ & $\begin{array}{l}\text { Small-cell or } \\
\text { non-small-cell lung } \\
\text { carcinoma, prostate } \\
\text { cancer, } \\
\text { gastrointestinal } \\
\text { cancer }\end{array}$ & $\begin{array}{l}\text { Clinical improvement or stabilization } \\
\text { in } 38 \% \text { treated with oncological } \\
\text { therapy with or without } \\
\text { immunotherapy }(N=80) \text { and in } 21 \% \\
\text { treated with immunotherapy alone } \\
(N=34)\end{array}$ \\
\hline $\begin{array}{l}\text { LGI1 (leucine-rich } \\
\text { glioma-inactivated } \\
\text { 1) }[25]\end{array}$ & Cell surface & $\begin{array}{l}\text { Limbic encephalitis, } \\
\text { faciobrachial dystonic } \\
\text { seizures, abnormal sleep } \\
\text { behavior }\end{array}$ & $5-10 \%$ & Thymoma & $\begin{array}{l}50 \% \text { improve with first-line } \\
\text { immunotherapy, and } 71 \% \text { at } \\
24 \text { months had a good outcome } \\
(N=48)\end{array}$ \\
\hline
\end{tabular}


Table 17.1 (continued)

\begin{tabular}{|c|c|c|c|c|c|}
\hline Antibody & $\begin{array}{l}\text { Antigen } \\
\text { class }\end{array}$ & $\begin{array}{l}\text { Syndromes and associated } \\
\text { neurological findings }\end{array}$ & $\begin{array}{l}\text { Frequency } \\
\text { of cancer }\end{array}$ & Main cancer type & Response to immunotherapy \\
\hline Ma1 or Ma2 [76] & Intracellular & $\begin{array}{l}\text { Limbic encephalitis, } \\
\text { brainstem encephalitis, } \\
\text { hypothalamic encephalitis, } \\
\text { mesencephalic encephalitis, } \\
\text { subacute cerebellar } \\
\text { degeneration }\end{array}$ & $>95 \%$ & $\begin{array}{l}\text { Ma 1: various lung } \\
\text { cancers; Ma2: } \\
\text { testicular cancer, } \\
\text { seminomas }\end{array}$ & $\begin{array}{l}\text { With various immunotherapy } \\
\text { regimens, } 36 \% \text { improved and } 46 \% \\
\text { were stable }(N=24)\end{array}$ \\
\hline \multicolumn{6}{|l|}{ Other encephalitides } \\
\hline $\begin{array}{l}\text { MOG (myelin } \\
\text { oligodendrocyte } \\
\text { glycoprotein) [77, } \\
78]\end{array}$ & Cell surface & $\begin{array}{l}\text { Acute disseminated } \\
\text { encephalomyelitis (ADEM), } \\
\text { neuromyelitis optica, optic } \\
\text { neuritis, myelitis }\end{array}$ & $0 \%$ & None & $\begin{array}{l}\text { Varies by presentation, with brainstem } \\
\text { encephalitis and encephalitis least } \\
\text { common ( } 14 \% \text { total). MOG antibodies } \\
\text { may be transiently present in } \\
\text { postinfectious disorders such as } \\
\text { ADEM. Based on data from patients } \\
\text { with optic neuritis and those with } \\
\text { myelitis }(N=62) \text {, complete recovery } \\
\text { in } 35-52 \% \text {, partial response in } \\
40-65 \%\end{array}$ \\
\hline $\begin{array}{l}\text { NMDA receptor } \\
{[20]}\end{array}$ & $\begin{array}{l}\text { Synaptic } \\
\text { receptor }\end{array}$ & $\begin{array}{l}\text { Anti-NMDA receptor } \\
\text { encephalitis with anxiety, } \\
\text { psychosis, epilepsy, } \\
\text { extrapyramidal disorder, } \\
\text { hypoventilation, central } \\
\text { dysautonomia }\end{array}$ & $\begin{array}{l}\text { Varies with } \\
\text { age and sex; } \\
38 \% \text { across } \\
\text { the } \\
\text { population }\end{array}$ & Ovarian teratoma & $\begin{array}{l}\text { Of those treated with first-line } \\
\text { immunotherapy alone or with teratoma } \\
\text { resection, } 50 \% \text { improve at } 4 \text { weeks. Of } \\
\text { those not improved at } 4 \text { weeks and } \\
\text { then given second-line therapy, } 67 \% \\
\text { with a complete or mild disability at } \\
24 \text { months }(N=472)\end{array}$ \\
\hline $\begin{array}{l}\text { Dopamine } 2 \\
\text { receptor [79] }\end{array}$ & $\begin{array}{l}\text { Synaptic } \\
\text { receptor }\end{array}$ & $\begin{array}{l}\text { Basal ganglia encephalitis, } \\
\text { Sydenham chorea }\end{array}$ & $0 \%$ & None or unknown & $\begin{array}{l}\text { Limited case series with } 7 \text { patients } \\
\text { treated with immunotherapy, either } \\
\text { corticosteroids or corticosteroids with } \\
\text { IVIG, } 5 \text { with clinical improvement. } \\
\text { Suggestion that more aggressive IV } \\
\text { methylprednisolone + IVIG has a } \\
\text { better outcome }\end{array}$ \\
\hline Aquaporin 4 [80] & Cell surface & $\begin{array}{l}\text { Encephalitis, neuromyelitis } \\
\text { optica (NMO), optic neuritis, } \\
\text { myelitis }\end{array}$ & $0 \%$ & None & $\begin{array}{l}\text { Rarely, NMO patients may present } \\
\text { with encephalopathies or encephalitis } \\
\text { syndromes. Overall, patients with } \\
\text { NMO respond well to immune } \\
\text { therapy. 53\% who received first-line } \\
\text { immunotherapy (IV } \\
\text { methylprednisolone alone or followed } \\
\text { by plasmapheresis if limited response } \\
\text { to corticosteroids) without motor } \\
\text { disability }(N=15)\end{array}$ \\
\hline $\begin{array}{l}\text { DPPX (dipeptidyl- } \\
\text { peptidase-like } \\
\text { protein 6) [81] }\end{array}$ & Cell surface & $\begin{array}{l}\text { Encephalitis, psychiatric } \\
\text { symptoms, diarrhea, tremor, } \\
\text { nystagmus, hyperekplexia, } \\
\text { ataxia, progressive } \\
\text { encephalomyelitis with } \\
\text { rigidity and myoclonus } \\
\text { (PERM) }\end{array}$ & $<10 \%$ & Lymphoma & $\begin{array}{l}44 \% \text { with complete or near complete } \\
\text { recovery, } 33 \% \text { with a mild disability } \\
\text { after immunotherapy }(N=9)\end{array}$ \\
\hline $\begin{array}{l}\mathrm{GABA}_{\mathrm{A}} \text { receptor } \\
{[31]}\end{array}$ & $\begin{array}{l}\text { Synaptic } \\
\text { receptor }\end{array}$ & $\begin{array}{l}\text { Encephalitis, epilepsy, } \\
\text { cerebellar ataxia }\end{array}$ & $<5 \%$ & Thymoma & $\begin{array}{l}28 \% \text { complete, } 72 \% \text { partial clinical } \\
\text { improvement after immunotherapy } \\
\text { and oncologic therapy }(N=21)\end{array}$ \\
\hline mGluR5 [82] & $\begin{array}{l}\text { Synaptic } \\
\text { receptor }\end{array}$ & Encephalitis & $55 \%$ & $\begin{array}{l}\text { Hodgkin's } \\
\text { lymphoma, } \\
\text { small-cell lung } \\
\text { cancer }\end{array}$ & $\begin{array}{l}55 \% \text { with complete recovery and } 45 \% \\
\text { with partial recovery following } \\
\text { treatment with immunotherapy } \\
(N=4) \text {, immunotherapy and } \\
\text { oncologic therapy }(N=4) \text {, oncological } \\
\text { therapy alone }(N=2) \text {, or none }(N=1)\end{array}$ \\
\hline
\end{tabular}


Table 17.2 Case series of anti-NMDAR encephalitis

\begin{tabular}{|c|c|c|c|c|c|c|c|c|c|c|c|c|}
\hline \multicolumn{13}{|l|}{ Anti-NMDAR encephalitis } \\
\hline Study & No & Age $(-/+)$ & $\begin{array}{l}\text { ICU } \\
(\%)\end{array}$ & $\begin{array}{l}\text { Psych } \\
(\%)\end{array}$ & $\begin{array}{l}\text { Cog } \\
(\%)\end{array}$ & $\begin{array}{l}\mathrm{Se} \\
(\%)\end{array}$ & $\begin{array}{l}\mathrm{SE} \\
(\%)\end{array}$ & $\begin{array}{l}\text { RSE } \\
(\%)\end{array}$ & $\begin{array}{l}\text { Mov } \\
(\%)\end{array}$ & $\begin{array}{l}\text { Dys } \\
(\%)\end{array}$ & $\begin{array}{l}\text { Int } \\
(\%)\end{array}$ & $\begin{array}{l}\text { Mort } \\
(\%)\end{array}$ \\
\hline $\begin{array}{l}\text { Titulaer et al. Late-onset encephalitis. } \\
\text { Multicenter multination study. Spain, } 2013 \\
\text { [83] }\end{array}$ & 31 & $\begin{array}{l}52 \\
(45-84)\end{array}$ & $\begin{array}{l}27 \\
(87)\end{array}$ & $\begin{array}{l}31 \\
(100)\end{array}$ & $\begin{array}{l}26 \\
(84)\end{array}$ & $4(13)$ & - & - & $\begin{array}{l}21 \\
(68)\end{array}$ & $\begin{array}{l}13 \\
(42)\end{array}$ & $\begin{array}{l}10 \\
(32)\end{array}$ & $5(16)$ \\
\hline $\begin{array}{l}\text { Titulaer et al. Treatment and prognosis for } \\
\text { long-term outcomes. Multicenter multination } \\
\text { study. Spain, } 2013 \text { [20] }\end{array}$ & 577 & $\begin{array}{l}21 \\
(0.33-85)\end{array}$ & $\begin{array}{l}435 \\
(77)\end{array}$ & $\begin{array}{l}238 \\
(65)^{\mathrm{a}}\end{array}$ & $\begin{array}{l}288 \\
(85)^{\mathrm{a}}\end{array}$ & $\begin{array}{l}230 \\
(68)^{\mathrm{a}}\end{array}$ & - & - & $\begin{array}{l}241 \\
(71)^{\mathrm{a}}\end{array}$ & $\begin{array}{l}166 \\
(49)^{\mathrm{a}}\end{array}$ & $\begin{array}{l}139 \\
(41)^{\mathrm{a}}\end{array}$ & $7(5)^{\mathrm{a}}$ \\
\hline $\begin{array}{l}\text { Chi et al. Risk factors for mortality in } \\
\text { encephalitis. Single center single nation study. } \\
\text { China, } 2017 \text { [58] }\end{array}$ & 96 & $\begin{array}{l}24.5 \\
(9-71)\end{array}$ & $\begin{array}{l}13 \\
(14)\end{array}$ & $\begin{array}{l}87 \\
(90.6)\end{array}$ & $\begin{array}{l}15 \\
(16)\end{array}$ & $\begin{array}{l}77 \\
(80)\end{array}$ & $\begin{array}{l}29 \\
(30)\end{array}$ & $\begin{array}{l}13 \\
(14)\end{array}$ & - & $6(6)$ & $\begin{array}{l}13 \\
(14)\end{array}$ & $\begin{array}{l}11 \\
(12)\end{array}$ \\
\hline $\begin{array}{l}\text { de Montmollin et al. Adults with encephalitis } \\
\text { in UCI. Multicenter multination study. France, } \\
2017 \text { [30] }\end{array}$ & 76 & $\begin{array}{c}24 \\
(20-31)\end{array}$ & $\begin{array}{l}133 \\
(72)\end{array}$ & - & $\begin{array}{l}31 \\
(41)\end{array}$ & $\begin{array}{l}30 \\
(39)\end{array}$ & $\begin{array}{l}34 \\
(45)\end{array}$ & $\begin{array}{l}28 \\
(37)\end{array}$ & - & $2(3)$ & $\begin{array}{l}59 \\
(78)\end{array}$ & $7(4)$ \\
\hline $\begin{array}{l}\text { Wang et al. Encephalitis in pediatric } \\
\text { population. Single center single nation study. } \\
\text { China, } 2017 \text { [65] }\end{array}$ & 51 & $\begin{array}{c}8 \\
(0.33-14)\end{array}$ & $\begin{array}{l}7 \\
(14)\end{array}$ & $30(55)$ & $\begin{array}{l}26 \\
(51)\end{array}$ & $\begin{array}{l}34 \\
(67)\end{array}$ & $\begin{array}{l}14 \\
(27)\end{array}$ & - & - & $\begin{array}{l}12 \\
(24)\end{array}$ & $7(23)$ & 0 \\
\hline $\begin{array}{l}\text { Gable et al. Encephalitis in pediatric } \\
\text { population. Multicenter single nation study. } \\
\text { USA, } 2017 \text { [29] }\end{array}$ & 24 & $\begin{array}{l}10.5 \\
(2-18)\end{array}$ & $\begin{array}{l}10 \\
(54)\end{array}$ & $16(66)$ & - & $\begin{array}{l}16 \\
(66)\end{array}$ & - & - & $\begin{array}{l}19 \\
(79)\end{array}$ & $\begin{array}{l}13 \\
(54)\end{array}$ & $8(33)$ & $1(4)$ \\
\hline $\begin{array}{l}\text { de Bruijn et al. Neuropsychological outcome in } \\
\text { pediatric population. Multicenter single nation } \\
\text { study. Netherlands, } 2018 \text { [84] }\end{array}$ & 28 & $14(1-17)$ & $\begin{array}{l}13 \\
(46)\end{array}$ & $27(96)$ & $\begin{array}{l}26 \\
(93)\end{array}$ & $\begin{array}{l}24 \\
(86)\end{array}$ & - & - & $\begin{array}{l}24 \\
(86)\end{array}$ & $\begin{array}{l}15 \\
(24)\end{array}$ & $4(14)$ & - \\
\hline $\begin{array}{l}\text { Ho et al. Encephalitis in pediatric population. } \\
\text { Multicenter single nation study. China, } 2018 \\
\text { [85] }\end{array}$ & 15 & $12(1-17)$ & $\begin{array}{l}10 \\
(67)\end{array}$ & $14(93)$ & $\begin{array}{l}14 \\
(93)\end{array}$ & - & - & $\begin{array}{l}12 \\
(80)\end{array}$ & $5(33)$ & $\begin{array}{c}2 \\
(13.3)\end{array}$ & - & \\
\hline $\begin{array}{l}\text { Granata et al. Movement disorders in Pediatric } \\
\text { encephalitis. Single center single nation study. } \\
\text { Italy, } 2018 \text { [86] }\end{array}$ & 18 & $\begin{array}{l}12.4 \\
(12-17.5)\end{array}$ & $1(6)$ & $5(28)$ & $\begin{array}{l}16 \\
(89)\end{array}$ & $\begin{array}{l}17 \\
(94)\end{array}$ & - & - & $\begin{array}{l}18 \\
(100)\end{array}$ & $\begin{array}{c}7 \\
(41.1)\end{array}$ & - & $1(6)$ \\
\hline $\begin{array}{l}\text { Zhang et al. Late-onset encephalitis. Single } \\
\text { center single nation study. China, } 2018 \text { [87] }\end{array}$ & 18 & $\begin{array}{l}51.5 \\
(45-78)\end{array}$ & $1(6)$ & $73(60)$ & $5(4)$ & $2(11)$ & $1(6)$ & $1(6)$ & $6(33)$ & $6(33)$ & $3(17)$ & $1(6)$ \\
\hline $\begin{array}{l}\text { Mueller et al. Genetic predisposition in } \\
\text { encephalitis. Multicenter multination study. } \\
\text { Germany, } 2018 \text { [88] }\end{array}$ & 96 & $\begin{array}{l}30.3 \\
(17-44)\end{array}$ & $\begin{array}{l}44 \\
(42)\end{array}$ & $88(92)$ & - & $\begin{array}{l}70 \\
(73)\end{array}$ & - & - & $\begin{array}{l}43 \\
(45)\end{array}$ & $\begin{array}{l}37 \\
(39)\end{array}$ & - & - \\
\hline
\end{tabular}

ICU intensive care unit, Psych psychiatric, $C o g$ cognitive, Se seizures, SE status epilepticus, RSE refractory status epilepticus, Mov movement disorders, Dys dysautonomia, Int intubation/hypoventilation, Mort mortality

'Only adults' data was included

anti-LGI1 encephalitis. These immunotherapy (rather than antiepileptic) responsive seizures are very brief (on the order of seconds), frequent (median of 50 times per day in one series) unilateral or bilateral jerking movements of the arm and ipsilateral face more often than leg $[18,26]$. High emotion or auditory or visual stimuli are triggers for FBDS in $28 \%$ of patients [26]. In those patients with anti-LGI1 encephalitis presenting with FBDS, earlier treatment with immunotherapy predicted improved outcomes in terms of cognition, disability, and seizure control [18, 19]. As has been observed in patients with antibody responses directed at cell surface proteins, anti-LGI1 is not strongly associated with a particular cancer, with only $7 \%$ of patients found to have a malignancy [26].

The subsequent diagnostic evaluation of a patient with suspected autoimmune encephalitis is directed not only at supporting a diagnosis of autoimmune encephalitis and its sequelae to permit rapid treatment but also at assuring the absence of other etiologies of a subacute and progressive encephalopathy, particularly infectious encephalitides. When evaluating a patient with suspected autoimmune encephalitis, it is crucial to be mindful that the diagnosis of autoimmune encephalitis is clinical, incorporating clinical presentation with paraclinical findings, and is not solely dependent on the detection of an autoantibody. 
Table 17.3 Case series of anti-LGI encephalitis

\begin{tabular}{|c|c|c|c|c|c|c|c|c|c|}
\hline \multicolumn{10}{|l|}{ Anti-LGI1 encephalitis } \\
\hline Study & No & $\begin{array}{l}\text { Age } \\
(-/+)\end{array}$ & $\begin{array}{l}\text { ICU } \\
(\%)\end{array}$ & $\begin{array}{l}\text { Psych } \\
(\%)\end{array}$ & $\begin{array}{l}\text { Cog } \\
(\%)\end{array}$ & $\operatorname{Se}(\%)$ & $\begin{array}{l}\text { SE } \\
(\%)\end{array}$ & $\begin{array}{l}\text { Dys } \\
(\%)\end{array}$ & $\begin{array}{l}\text { Mort } \\
(\%)\end{array}$ \\
\hline $\begin{array}{l}\text { Finke et al. Cognitive deficits and structural hippocampal damage } \\
\text { in encephalitis. Multicenter single nation study. Germany, } 2017 \\
\text { [89] }\end{array}$ & 30 & $\begin{array}{l}65.7 \\
(12.3)\end{array}$ & - & $11(37)$ & $\begin{array}{l}30 \\
(100)\end{array}$ & 28(93) & - & - & $1(3)$ \\
\hline $\begin{array}{l}\text { Gao et al. Clinical characterization of autoimmune LGI1 antibody } \\
\text { limbic encephalitis. Single center single nation study. China, } 2016 \\
\text { [90] }\end{array}$ & 10 & $\begin{array}{l}51.5 \\
(27-75)\end{array}$ & - & $2(20)$ & $9(90)$ & $10(100)$ & $1(10)$ & - & 2(20) \\
\hline $\begin{array}{l}\text { Celicanin et al. Autoimmune encephalitis associated with LGI1 ab. } \\
\text { Denmark, } 2017 \text { [91] }\end{array}$ & 16 & $\begin{array}{c}62 \\
(29-84)\end{array}$ & - & $5(31)$ & $\begin{array}{l}10 \\
(63)\end{array}$ & $6(38)$ & - & $4(25)$ & $1(6.2)$ \\
\hline $\begin{array}{l}\text { Irani et al. Faciobrachial dystonic seizures precede limbic } \\
\text { encephalitis. Multicenter multination study. UK, } 2011 \text { [26] }\end{array}$ & 29 & $\begin{array}{c}64 \\
(36-83)\end{array}$ & $1(3)$ & - & $\begin{array}{l}19 \\
(66)\end{array}$ & 26(77) & - & $5(19)$ & - \\
\hline $\begin{array}{l}\text { Mueller et al. Genetic predisposition in encephalitis. Multicenter } \\
\text { multination study. Germany, } 2018 \text { [88] }\end{array}$ & 54 & $\begin{array}{l}62.7 \\
(51-74)\end{array}$ & $4(7)$ & $31(57)$ & - & $41(76)$ & - & $6(12)$ & - \\
\hline
\end{tabular}

ICU intensive care unit, Psych psychiatric, Cog cognitive, Se seizures, SE status epilepticus, Dys dysautonomia, Mort mortality

\section{Diagnostic Evaluation}

Diagnostic studies incorporated in the evaluation for possible autoimmune encephalitis include autoantibody testing along with common and widely performed paraclinical diagnostics: CSF studies, electroencephalography, and brain MRI. We will consider each briefly in turn as well as the developing role of brain fluorodeoxyglucose-positron emission tomography (FDG-PET) as a diagnostic modality. In addition, the evaluation includes assessing for occult malignancy in the event that the encephalitis is a paraneoplastic syndrome.

\section{Antibody Testing}

Several autoantibodies have been described in association with autoimmune encephalitis (Table 17.1), each serving as either a marker of an autoimmune response or in a direct pathogenic capacity [4, 27]. Patients with possible autoimmune encephalitis should be tested for the presence of antibodies not only in the serum but also in the CSF [5]. This advisement is made since in some, but not all, autoimmune encephalitis syndromes (e.g., antiNMDAR encephalitis), CSF antibody assays are more sensitive than those in the serum $[5,20,25]$. CSF antibody testing allows for greater specificity as it is not uncommon for multiple antibodies to be detected in the serum, with only one antibody detected in paired CSF that more likely reflects the underlying immune response [5]. Thus, CSF antibody testing has a lower rate of falsepositive and false-negative results than testing in the serum alone [5].

\section{CSF Testing}

In addition to antibody testing, CSF testing plays an essential role in the initial management of a patient suspected to have autoimmune encephalitis, both to support the possibility of this diagnosis and to evaluate for other potential diagnoses. Moderate lymphocytic-predominant CSF pleocytosis $(>/=5$ white blood cells/milliliter) is a criterion incorporated in the most recent consensus clinical criteria; however, this finding may depend on syndromic timing. Late in the disease course, no abnormalities may be noted in the CSF except for an elevated protein level. Elevated CSF to serum immunoglobulin $\mathrm{G}$ index and intrathecal oligoclonal bands are also supportive, though not diagnostic, of an intrathecal autoimmune response. It is, however, important to note that CSF glucose at a depressed level relative to serum would be more suggestive of an infectious etiology than autoimmune encephalitis.

\section{Electroencephalography (EEG)}

EEG findings are also included in the consensus criteria, namely, temporal lobe slowing (bilateral or unilateral) and electrographic seizures ranging from focal to generalized and including nonconvulsive and convulsive status epilepticus that may be refractory $[5,9,28]$. Otherwise, EEG itself is variable in its sensitivity across the autoimmune encephalitides, with slowing and disorganized activity being the most frequent findings [5]. Some rare electrographic findings have been described in specific syndromes, such as extreme delta brush in anti-NMDAR encephalitis; however, such findings appear to be the exception rather than the rule [29]. 


\section{MRI}

Although brain MRI is an important diagnostic tool in the evaluation of encephalitis, around $75 \%$ of cases of autoimmune encephalitis do not demonstrate abnormalities on MRI. Clinical consensus criteria include T2/FLAIR (fluidattenuated inversion recovery) hyperintensities of the medial temporal lobes or multifocal T2/FLAIR hyperintensities of the gray matter, white matter, or a combination of the two - suggestive of demyelination or inflammation
(Fig. 17.1) [5]. The most frequently affected areas are the frontal cortex, basal ganglia, thalamus, temporal lobe, cerebellum, and insula $[29,30]$. The sensitivity of such abnormalities vary, from $93 \%$ when evaluated for among patients otherwise meeting the consensus criteria for probable or definite autoimmune encephalitis in one series to approximately half of patients with anti-NMDAR encephalitis and $10-20 \%$ of patients with anti-LGI1 encephalitis presenting with FBDS $[2,18,20]$. In addition, such findings can be mild, transient, associated with only subtle contrast
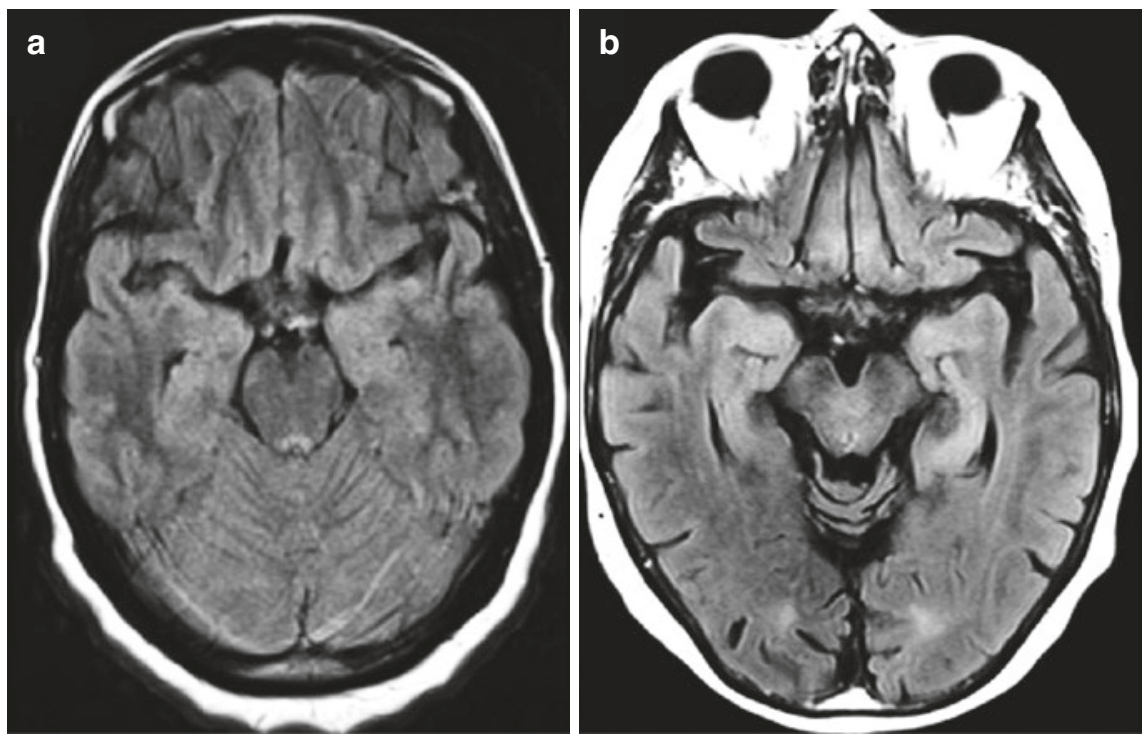

d

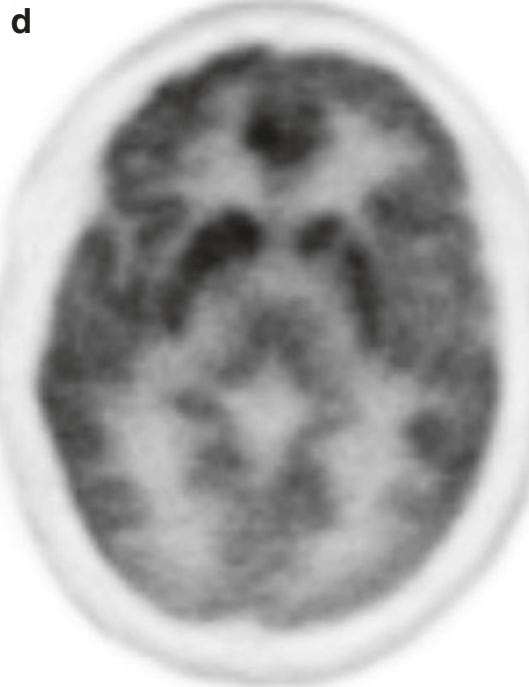

e

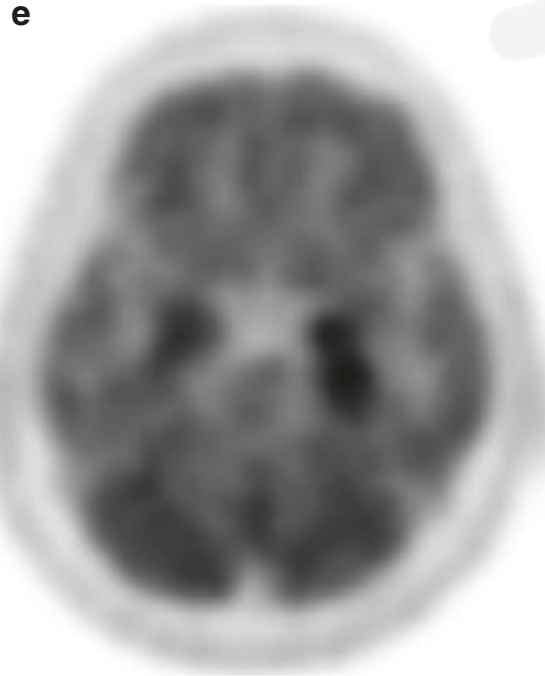

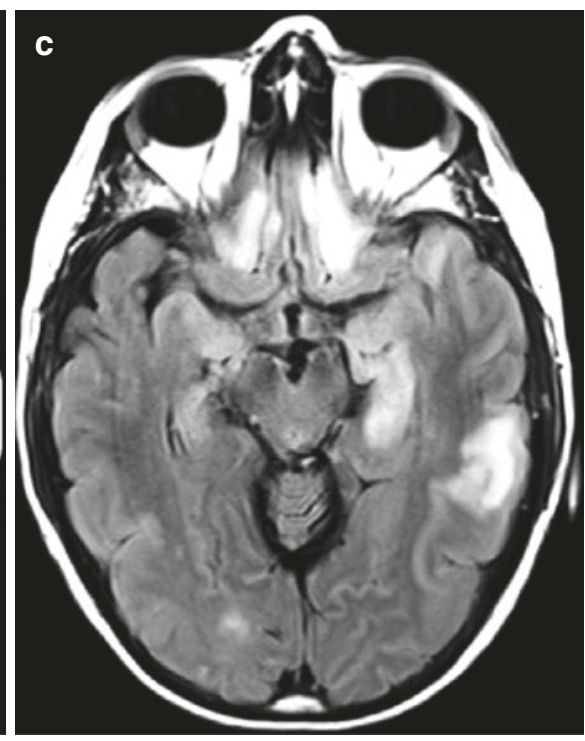

f

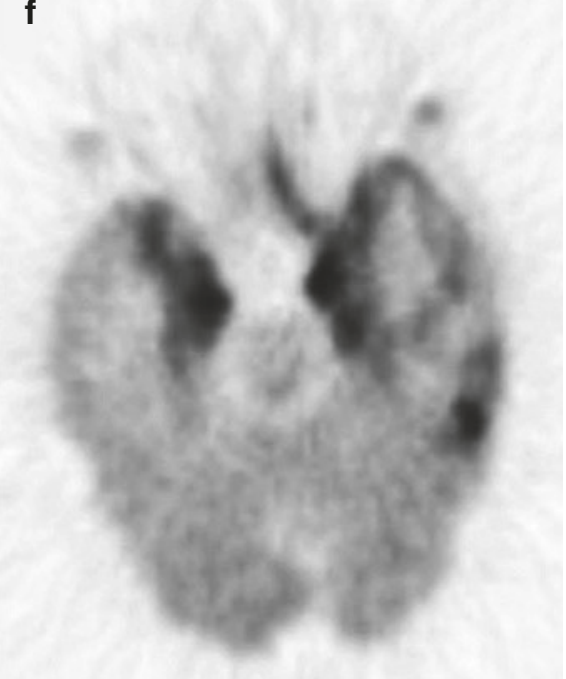

Fig. 17.1 Examples of brain MRI and FDG-PET findings in autoimmune encephalitis. Brain MRI: (a) Subtle T2 hippocampal T2/ FLAIR hyperintensities in a patient in the acute phase of antiNMDAR encephalitis. (b) T2/FLAIR hyperintensities in the bilateral medial temporal lobes of a patient in the acute phase of anti-LGI1 encephalitis. (c) Multifocal T2/FLAIR hyperintensities involving the left more so than right hippocampi and gray and sub- cortical white matter of the temporal lobes in a patient with antiGAD65 encephalitis. Brain FDG-PET/CT: (d) Marked cortical hypometabolism in the same patient with anti-NMDAR encephalitis. (e) Areas of hypermetabolism of the bilateral hippocampi in the same patient with anti-LGI1 encephalitis. (f) Areas of hypermetabolism in the bilateral medial temporal lobes in the same patient with anti-GAD65 encephalitis 
enhancement, or even asynchronous (some appear while others disappear) in appearance, as has been recently described in anti-GABA $\mathrm{A}_{\mathrm{A}}$ receptor antibody-associated encephalitis [31]. A common late finding, particularly in the subset of autoimmune limbic encephalitides, is the development of mesial temporal lobe sclerosis [18, 31, 32]. Selective involvement of diencephalic structures or brainstem is characteristic of some autoimmune encephalitides such as those associated with Ma-Ta antibodies [4].

\section{FDG-PET}

Though included in early descriptions, such as that for antiNMDAR encephalitis, dedicated brain FDG-PET imaging has recently attracted growing interest as a potential diagnostic and monitoring test in autoimmune encephalitis [3335]. Hypermetabolism by FDG-PET of the medial temporal lobes is included in the clinical consensus criteria for definite limbic encephalitis but not those for autoimmune encephalitis in general [5]. Case series reporting a gradient of occipital hypometabolism to frontotemporal hypermetabolism in anti-NMDAR encephalitis, hypermetabolism of the basal ganglia and medial temporal lobes in anti-LGI1 encephalitis, and normalization of these abnormalities with improvement in functional status suggest an expanded utility of FDG-PET in the evaluation and clinical monitoring of patients with autoimmune encephalitis $[26,35]$. As the clinical value of brain FDG-PET is evaluated in the future, it will be important for researchers and clinicians to be mindful that abnormal patterns of cerebral metabolism on FDGPET also have been well-described in neurodegenerative syndromes that can present with subacute cognitive decline, such as posterior cerebral atrophy and Lewy body dementia, which are both associated with occipital hypometabolism [36]. In addition, treatments commonly prescribed to patients in the acute phase of autoimmune encephalitis, such as corticosteroids and antiepileptic medications, have been observed to alter cortical metabolism [37, 38].

\section{Biopsy of Brain Tissue}

A biopsy of brain tissue is not generally used to diagnose autoimmune encephalitis for several reasons. Neuropathological findings such as infiltration by lymphocytes or microglia activation are frequently nonspecific and nondiagnostic. Also, one study found that brain biopsy contributed to diagnosis in only $8 \%$ of patients with autoimmune encephalitis [39]. Finally, antibody testing as described above yields more specific diagnoses and is noninvasive.

\section{Evaluation for Occult Malignancy}

As autoimmune encephalitis is considered a classic paraneoplastic syndrome, the clinical evaluation of a patient suspected to have this condition entails an assessment for an occult malignancy [40]. Some tumors produce peptides that are similar to those found in the nervous system, leading to immune cross-reactivity and paraneoplastic neurological syndromes. In particular, the immune system reacts against tumors leading to the development of cytotoxic and antibody-mediated responses directed not only at the tumor but also against the nervous system. In $80 \%$ of cases, neurological manifestations develop before the cancer diagnosis [41]. Paraneoplastic disorders usually develop during the early stages of cancer, so the tumor may be difficult to find. If detected, an antibody can guide monitoring for strongly associated tumors. A patient should be followed with regular diagnostic imaging to screen for an occult malignancy at regular intervals for 4 years. Studies have shown that after this time, the likelihood of detecting cancer is low [42].

\section{Differential Diagnostic Considerations}

The preceding discussion focused on the diagnostic value of each respective study for autoimmune encephalitis. In parallel, other diagnostic possibilities should be simultaneously evaluated for and eliminated as potential diagnoses. Differential considerations for a subacute, rapidly progressive encephalopathy include infection (e.g., encephalitis or meningoencephalitis due to herpes simplex virus, varicella zoster virus, human immunodeficiency virus (HIV), enterovirus, Cryptococcus, syphilis, and prion disease), encephalopathy due to systemic disease (e.g., sepsis, organ failure, vitamin deficiency, electrolyte abnormalities), rheumatologic and systemic autoimmune disease (e.g., systemic lupus erythematosus), illicit (e.g., ketamine) or prescribed (e.g., anticholinergic, neuroleptic, serotonergic) drug toxicity or withdrawal, metabolic disorder (e.g., mitochondrial and urea cycle disorders), cerebrovascular disease (e.g., recurrent ischemic stroke), cancer (e.g., primary and secondary brain cancers), and seizure (e.g., nonconvulsive status epilepticus) [5, 43, 44]. A detailed clinical history with brain imaging by MRI, CSF analysis, and EEG can be invaluable in the early period of hospitalization to rapidly sift through this broad differential as well as gather information to support the diagnosis of autoimmune encephalitis.

This diagnosis should be made based on the clinical presentation, and diagnostic evaluation should not be reserved for those with a detected commercially testable antibody nor 
applied to those who respond to systemic immunotherapy. From a practical perspective, antibody testing may not always be readily accessible and, if performed, the results may take weeks to return. In addition, there is a growing catalog of described antibody-associated autoimmune encephalitis syndromes, some of which are not testable at the commercial laboratory level. Thus, failure to detect an antibody in the serum or CSF does not exclude the possibility of autoimmune encephalitis in the appropriate clinical scenario but rather argues for the testing of serum and CSF in a neuroimmunological referral center. With that said, falsepositive antibody results can occur. Finally, a variety of conditions respond by varying degrees to systemic immunosuppression, such as corticosteroids in the treatment of primary and secondary cancers of the brain as well as neurosarcoidosis. Together, these points emphasize the importance of the clinical presentation and a careful evaluation to identify those with autoimmune encephalitis.

As early recognition and initiation of immunotherapy appear to be associated with improved clinical outcome in autoimmune encephalitis, the diagnostic evaluation is directed at identifying those patients who may have autoimmune encephalitis, assessing for other encephalitis etiologies (particularly infectious), screening for occult malignancy, initiating immunotherapy with escalation as needed, and managing sequelae of the encephalitis syndrome. We will now turn to immunotherapy and the management of autoimmune encephalitis sequelae commonly encountered in the ICU.

\section{Immunotherapy}

As autoimmune encephalitis is relatively rare, guidelines for immunotherapeutic management are lacking. No controlled prospective clinical trials have been conducted to determine efficacy of treatments in autoimmune encephalitis. At the present, most of the treatments rely on extant understanding of disease mechanisms, expert opinion based on clinical experience and case series, and a few relatively small prospective trials. When considering acute immunotherapy options, it is important to consider the patient's comorbidities and phase of illness at presentation. Serological status, if known, may guide agent selection and prognostication of recovery. It is essential to mention that delay in therapy initiation could worsen outcomes [45].

First-line immunotherapies for autoimmune encephalitis include intravenous (IV) corticosteroids (typically methylprednisolone), intravenous immunoglobulin (IVIG), and plasmapheresis (PLEX) (Table 17.4). Second-line therapies commonly used include rituximab and cyclophosphamide (Table 17.4), while mycophenolate and azathioprine are typically reserved for maintenance of immunosuppression after the acute phase of the illness. Patients seropositive for autoantibodies directed at cell surface proteins tend to respond well to antibody-directed therapies (i.e., IVIG and PLEX). These typically follow or accompany courses of IV corticosteroids. Consideration for selection of IVIG versus PLEX relies on patient status and active additional medical concerns $[46,47]$.

Corticosteroids are a helpful class of medications in a variety of autoimmune disorders, but their prolonged use is associated with multiple comorbidities including insulin resistance, diabetes mellitus, osteopenia, and increased risk for opportunistic infections. IVIG may be associated with a higher risk for chemical meningitis, hyperviscosity, and thrombotic syndromes. In addition, IVIG occasionally triggers headache, flushing, chest tightness, fever, chills, myalgias, fatigue, dyspnea, back pain, nausea, vomiting, diarrhea, and tachycardia and infrequently acute renal failure, neutropenia, autoimmune hemolytic anemia, skin reactions, and arthritis. PLEX can result in decreased arterial blood pressure, arrhythmias, sensations of cold with temporarily elevated temperature, paresthesias, and rarely life-threatening conditions (e.g., shock, hypotension, persistent arrhythmias, hemolysis) [48-50].

Immune absorption (IA) is an alternative therapy to PLEX, although this medication is not yet available in many countries, including the United States. Studies have suggested an at least equivalent efficacy of IA compared to PLEX [51, 52]. IA allows rapid and selective elimination of antibodies, making this medication an excellent option. IA produces an immediate intravascular reduction of antibody and immune complex concentration as well as antibody redistribution that causes subsequent immunomodulatory changes. While PLEX is a nonselective medication and associated with a reduction in coagulation factors, IA is selective and has fewer adverse effects. In a retrospective analysis of 30 patients with autoimmune encephalitis treated with PLEX or IA, 65\% improved after PLEX and $100 \%$ after IA [51]. Furthermore, a retrospective analysis of 13 patients with autoimmune encephalitis treated with IA showed that $85 \%$ had improvement of their symptoms; however, this efficacy could not be completely attributed to IA because most patients were treated with concomitant corticosteroids [53].

When a detected antibody is directed to an intracellular protein, therapies directed at the cell-mediated immune response rather than immunomodulatory therapies are advocated $[46,47]$. In the acute setting, therefore, cyclophosphamide plays an important role in suppressing the cytotoxic response with the aim of reducing the extent of neuronal injury due to the cell-mediated immune response [46, 47].

No guidelines exist to otherwise guide the selection of first-line immunotherapy nor subsequent escalation to 
Table 17.4 Common acute immunotherapies for autoimmune encephalitis

\begin{tabular}{|c|c|c|c|c|}
\hline Therapies & $\begin{array}{l}\text { Initial treatment } \\
\text { regimen }\end{array}$ & Time to response & Pretreatment management & Side effects \\
\hline \multicolumn{5}{|l|}{ First-line } \\
\hline $\begin{array}{l}\text { Intravenous } \\
\text { methylprednisolone }\end{array}$ & $\begin{array}{l}1000 \mathrm{mg} \text { daily for } \\
3-5 \text { days }\end{array}$ & $\begin{array}{l}\text { Days to weeks } \\
\text { with benefit for } \\
\text { weeks }\end{array}$ & $\begin{array}{l}\text { Assess for hypertension, baseline serum } \\
\text { glucose and electrolytes, close glucose } \\
\text { monitoring and consideration for insulin } \\
\text { adjustments in known diabetics }\end{array}$ & $\begin{array}{l}\text { Insomnia, psychiatric symptoms, } \\
\text { hyperglycemia (close glucose } \\
\text { monitoring with sliding scale } \\
\text { insulin advised), electrolyte } \\
\text { abnormalities, fluid retention, } \\
\text { hypertension, peptic ulcer (gastric } \\
\text { ulcer prophylaxis advised), } \\
\text { Cushing syndrome, cataracts, } \\
\text { infection, osteoporosis, avascular } \\
\text { necrosis (patients should be } \\
\text { advised of risk and monitored for), } \\
\text { addisonian crisis in setting of } \\
\text { rapid withdrawal }\end{array}$ \\
\hline $\begin{array}{l}\text { Intravenous } \\
\text { immunoglobulin }\end{array}$ & $\begin{array}{l}0.4 \mathrm{~g} / \mathrm{kg} / \text { day for } \\
5 \text { days }\end{array}$ & $\begin{array}{l}\text { Days to weeks } \\
\text { with benefit for } \\
\text { approximately a } \\
\text { month }\end{array}$ & $\begin{array}{l}\text { Consider IgA-level assessment; } \\
\text { premedication with acetaminophen and } \\
\text { diphenhydramine }\end{array}$ & $\begin{array}{l}\text { Headache, aseptic meningitis, } \\
\text { thromboembolic events, acute } \\
\text { renal failure, anaphylaxis in those } \\
\text { who are IgA deficient }\end{array}$ \\
\hline Plasmapheresis & $\begin{array}{l}5 \text { exchanges, } \\
\text { typically an } \\
\text { exchange every } \\
\text { other day. } \\
\text { Schedules vary by } \\
\text { institution }\end{array}$ & $\begin{array}{l}\text { Days to weeks } \\
\text { with benefit for } \\
\text { months }\end{array}$ & $\begin{array}{l}\text { Plasmapheresis catheter placement of } \\
\text { adequate caliber, assessment to assure no } \\
\text { active infection }\end{array}$ & $\begin{array}{l}\text { Hypotension, electrolyte } \\
\text { imbalance. With central line, } \\
\text { infection, hemorrhage, } \\
\text { thrombosis, and pneumothorax are } \\
\text { risks }\end{array}$ \\
\hline \multicolumn{5}{|l|}{ Second-line } \\
\hline Rituximab $^{\mathrm{a}}$ & $\begin{array}{l}1000 \mathrm{mg} \text { weekly } \\
\text { for } 2 \text { weeks, or } \\
375 \mathrm{mg} / \mathrm{m}^{2} \text { body } \\
\text { surface area } \\
\text { weekly for } \\
4 \text { weeks }\end{array}$ & Weeks & $\begin{array}{l}\text { Screening for hepatitis B and C, screening } \\
\text { for tuberculosis }\end{array}$ & $\begin{array}{l}\text { Allergic reaction, opportunistic } \\
\text { infection, reactivation of } \\
\text { tuberculosis or hepatitis B }\end{array}$ \\
\hline $\begin{array}{l}\text { Intravenous } \\
\text { cyclophosphamide }\end{array}$ & $\begin{array}{l}500-1000 \mathrm{mg} / \mathrm{m}^{2} \\
\text { monthly for } \\
3-6 \text { months }\end{array}$ & Weeks & $\begin{array}{l}\text { Baseline complete blood cell count, liver } \\
\text { function tests, serum creatinine. Assure } \\
\text { adequate hydration over } 24 \mathrm{~h} \text { prior to dose } \\
(2-3 \mathrm{~L}) \text {, normal saline } 500 \mathrm{~mL} \text { intravenous } \\
1 \mathrm{~h} \text { prior to a dose, prochlorperazine or } \\
\text { ondansetron as nausea and vomiting } \\
\text { prophylaxis, mesna for hemorrhagic cystitis } \\
\text { prophylaxis }\end{array}$ & $\begin{array}{l}\text { Nausea, vomiting, alopecia, } \\
\text { mucositis, hemorrhagic cystitis, } \\
\text { infertility, myelosuppression }\end{array}$ \\
\hline
\end{tabular}

${ }^{\mathrm{a}} \mathrm{Can}$ be used in both acute and maintenance phases of treatment

second-line treatments in the acute phase. Second-line treatments are typically considered once the period of anticipated response (around 2 weeks) to first-line treatment has passed as well as in severe presentations [20]. With that said, there is evidence to suggest a role for rituximab, a monoclonal antibody against $\mathrm{CD} 20$, as second-line immunotherapy for both seropositive and seronegative autoimmune encephalitis, with tolerability and improved outcomes observed [54, 55]. Furthermore, studies have shown good efficacy of rituximab in patients with IgG4 subtype antibodies, and IgG4 antibodies predominate in anti-LGI1 and anti-CASPR2 encephalitis.

The most common side effects of rituximab are infusionrelated reactions, infections, tiredness, and nausea; however, in general, it is a medication with a good safety profile. On the other hand, cyclophosphamide can potentially cause infertility among other side effects. Therefore, the collection of eggs and sperm and the administration of GnRH agonists in women are recommended [56].

\section{Complications of Autoimmune Encephalitis in the ICU}

As already stated, a large percentage of encephalitis patients require ICU admission. The most common reasons for ICU care in autoimmune encephalitis are altered mental status requiring intubation, status epilepticus/refractory status epilepticus, severe hyperkinetic movements, respiratory failure, autonomic dysfunction, and increased intracranial pressure (Tables 17.2 and 17.3). ICU level care, which is 
presumably linked to higher costs, is strongly associated with long-term outcome [39]. A recent study in a tertiary referral hospital showed that intensive care charges are around $\$ 173,000$ vs. $\$ 50,000$ for autoimmune encephalitis patients who do not require ICU admission [11]. In addition, the mortality rate of ICU-admitted patients ranges between $12 \%$ and $40 \%[13,39,57]$. The main causes of death are severe pneumonia, multiple organ dysfunction syndromes, and refractory status epilepticus [58].

\section{Status Epilepticus (SE) and Refractory Status Epilepticus (RSE)}

$\mathrm{SE}$ is a frequent, and sometimes the only, manifestation of autoimmune encephalitis. SE represents the principal cause for ICU admission and may evolve into RSE [58, 59]. Studies have reported generalized, nonconvulsive, partial, and complex seizures. In a cohort of patients with autoimmune encephalitis, $28 \%$ of patients suffered from SE for 7 or more days and required on average 5 antiepileptic medications [15].

SE treatment in autoimmune encephalitis centers on the use of antiepileptic medications for seizure control as well as immunosuppression [60]. There are validated protocols for seizure control in SE that include IV lorazepam, diazepam, and phenytoin or intramuscular midazolam or rectal diazepam as first-line therapy (Class I). Valproate and levetiracetam are second-line options (Class I-III), and IV sedative medications such as pentobarbital, propofol, or midazolam are used in case of failure of first- and second-line therapies. If seizures are uncontrolled, topiramate and phenobarbital can also be considered. Of note, phenobarbital is associated with more adverse effects such as hypotension and a high mortality rate. In addition, once infectious etiologies have been eliminated, first-line immunotherapy as per the discussion above should be rapidly initiated. In case of severe seizures, a vagus nerve stimulator or surgical resection of the seizure focus may be necessary [61]. Early diagnosis and treatment of SE/RSE are associated with better neurological outcomes and fewer relapses [62].

Another alternative for uncontrolled seizures with poor response to antiepileptic medications is the ketogenic diet (KD). This is a high-fat and low-carbohydrate diet that induces ketone bodies and has been effective in drug-resistant epilepsy in children and adults. The KD has been used in patients with anti-NMDAR encephalitis with success, and it is thus a potential therapy option [63]. A recent study in a tertiary referral center showed seizure control in $73 \%$ of patients with super-refractory SE after 2 days of the diet. At discharge, $67 \%$ were alive and the majority recovered to their baseline [64].

\section{Elevated Intracranial Pressure}

Intracranial hypertension is a well-known indication for ICU admission in patients with autoimmune encephalitis. Elevated intracranial pressure has been reported (in $34.4 \%$ and $21.5 \%$ of patients) in only two cohorts of patients with anti-NMDAR encephalitis [58, 65]. Given these reported frequencies, it is interesting that this condition has not been more widely reported, perhaps because it has not been previously identified as a predictor of poor prognosis or mortality. Given the potential for additional brain injury in the setting of persistent intracranial hypertension, further studies are necessary for evaluating the impact of this finding in patients' outcomes as well as its possible correlation with a specific syndrome. Acute management of elevated intracranial pressure may include interventions such as head of bed elevation, hyperventilation with normal oxygenation, careful blood pressure management, hyperosmolar or hypertonic saline therapy, IV corticosteroids, or neurosurgical interventions depending on etiology and clinical status.

\section{Dysautonomia}

Autonomic dysregulation has been reported in 25-45\% of patients with autoimmune encephalitis. Children are frequently less affected than adults. Common dysautonomic manifestations include fever without infection, hypoventilation or hyperventilation, tachycardia or bradycardia, blood pressure crises, diarrhea, hypersalivation, and erectile dysfunction. The presence of autonomic instability is a predictor of poor response to first-line immunotherapy. In addition, autonomic dysfunction appears to be associated with disease progression, particularly in anti-NMDAR encephalitis.

The underlying mechanism of autonomic instability is not clearly understood. Cardiac function is the result of a careful balance between the bradycardiogenic parasympathetic and the positive chronotropic sympathetic system [20]. An experimental study showed several brain regions that could potentially affect cardiac autonomic outflow such as the insula, anterior cingulate cortices, and amygdala, areas commonly involved in limbic encephalitis. Also, cardiac autonomic discharges can synchronize with epileptogenic activity triggering a lethal bradyarrhythmia or asystole [66].

Therefore, careful monitoring is necessary in all cases of autoimmune encephalitis. Dantrolene, external and internal cooling, pacemakers, mechanical ventilation, and hypertensive medications have been used in the management of dysautonomia in autoimmune encephalitis. In addition, temporary pacemakers have a Class I recommendation in 
cases of asystole, symptomatic bradycardia with hypotension that is not responsive to atropine, and bifascicular block. Certainly some patients require a permanent pacemaker as autonomic instability can last for several weeks or months $[20,66]$.

\section{Need for Mechanical Ventilation}

Mechanical ventilation is a common complication in patients with autoimmune encephalitis. In a recent study, $57 \%$ of patients were intubated for approximately 1 month on average [15]. Some required tracheostomy (68\%) and others developed ventilator-associated pneumonia (57\%) [15]. Reasons for mechanical ventilation include depressed level of consciousness, respiratory insufficiency, absent airway protection reflexes, hypoventilation, pneumonia, and sedation in psychosis or SE. Reported complications of mechanical ventilation are pneumonia, need for pleural drainage, and acute respiratory distress syndrome (ARDS).

\section{Triage and Administrative Considerations for Patients with Autoimmune Encephalitis}

With these complications in mind, the triage of a patient with autoimmune encephalitis is dependent not only on their neurological status but also on their overall medical status. In the emergency department setting, management begins with the clinical survey of airway, breathing, circulation, and glucose status. With the identification and treatment of potential vital sign-related issues, management progresses to the initial diagnostic evaluation including diagnosing autoimmune encephalitis and considering alternative diagnoses discussed earlier in this chapter. Patients may be treated empirically for some of these etiologies while awaiting diagnostic results (e.g. IV acyclovir for herpes simplex encephalitis while awaiting CSF test results). In addition, emergency room providers must assess for decreased or altered level of consciousness as well as their potential etiologies (e.g., seizure, elevated intracranial pressure due to cerebral edema). The management of each of these will likely continue through to triage to the ICU [67].

Intra- and inter-facility transfer discussions are founded on an understanding of a patient's cardiovascular, pulmonary, and neurological status, with emergent management (e.g., mechanical ventilation, treatment of SE) initiated before transfer.

Disposition from the emergency room or ICU varies by institution; however, it primarily depends on independence from mechanical ventilation, cardiovascular stability, normalization of intracranial pressure, and resolution of SE. Subsequent discharge from the hospital is most com- monly to an acute or subacute rehabilitation center for recovery, particularly for those who required prolonged ICU care.

Discussions regarding posthospital care should be held beginning at the time of admission, with plans made to address clinical issues as they arise, resolve, or persist throughout the course of hospitalization. The decision to transition from the acute care setting to rehabilitation or home is made upon completion of the diagnostic evaluation and treatment, which requires inpatient care. One should be mindful that the period of recovery following an episode of autoimmune encephalitis is on the order of weeks to months and is facilitated by directed physical, occupational, speech and language, and cognitive therapy. Psychiatric comanagement may also be required for those patients with psychiatric symptoms (e.g., psychosis), which will require longitudinal care. A critical factor in disposition planning is close hospital follow-up of not only diagnostic results and clinical recovery but also the identification and management of potential sequelae such as epilepsy.

Given the complexities entailed in managing patients with autoimmune encephalitis, their clinical care is collaborative and multidisciplinary. Intensivists, neurologists and neurological subspecialists, medical specialists, psychiatrists, and physiatrists have essential roles to play in collaboration with nursing staff, therapists, and pharmacists. The epoch of inpatient care can last weeks to months, with understandable strain on not only patients but also on their families and other loved ones. Social work, palliative care, and spiritual/chaplaincy services also play important roles in the care of patients with autoimmune encephalitis and their families throughout the hospitalization and during the transition to the outpatient setting.

\section{Prognosis}

Factors associated with poor neurologic outcomes are delay in administering immunotherapy, longer ICU stay, need for mechanical ventilation, intrathecal inflammation, severe sepsis, medical comorbidities, need for tracheostomy, and malignancy [30]. Furthermore, prognosis depends on the antibody subtype, with better prognosis for cases involving cell surface antigens and worse prognosis for those associated with paraneoplastic disorders and intracellular antigens.

Our understanding of the long-term neurobehavioral outcomes in autoimmune encephalitis is limited; some preliminary observations are hopeful, while others are sobering. In one large study of long-term outcomes of 77 patients with autoimmune encephalitis treated at a single tertiary center, $53 \%$ had a "good" functional outcome (modified Rankin Score $\leq 2)$. However, in detailed interviews, while $85 \%$ of patients were employed prior to developing autoimmune encephalitis, only $42 \%$ were employed afterward; in addi- 
tion, only $50 \%$ reported independence in traveling within their community, and $46 \%$ were responsible for their own finances [10]. In addition to these functional and practical aspects of recovery, patients commonly reported symptoms of fatigue, emotional lability, short-term memory loss, and difficulty with concentration years after the initial episode of autoimmune encephalitis [10]. Much work remains to characterize the outcomes and sequelae of autoimmune encephalitis in order to guide refinements to initial and longitudinal management of patients with this disorder.

\section{Future Directions}

There are still aspects of autoimmune encephalitis that remain unresolved, including the correlation of time to diagnosis and administration of immunotherapy versus outcomes and the elucidation of new serum, CSF, and radiological biomarkers that predict outcomes or measure disease activity. In addition, the role of brain FDG-PET in the diagnosis and prediction of outcomes needs to be clarified. Further studies are needed to determine a correlation between antibody titers and outcomes as well as the role of autonomic dysfunction and underlying malignancy in specific antibody subtypes. Work to thoroughly evaluate and clarify management strategies such as first-line versus second-line therapies, individual therapies, and new immunotherapies is also needed. Additionally, a detailed knowledge of postencephalitis sequelae is crucial to understand and attempt to ameliorate the impact on quality of life after the acute period.

\section{Conclusion}

Autoimmune encephalitis is a diverse category of primary autoimmune and secondary paraneoplastic syndromes that have gained increased attention over the past two decades. The diagnosis of autoimmune encephalitis is clinical, with outcomes dependent on early initiation of immunotherapy. Intensivists play a central role in the management of these patients, particularly in light of frequently associated complications such as SE, cardiovascular instability, and need for mechanical ventilation. ICU-level management is also critical given the high rate of mortality among patients with autoimmune encephalitis and to help optimize their outcomes.

\section{References}

1. Granerod J, Tam CC, Crowcroft NS, Davies NWS, Borchert M, Thomas SL. Challenge of the unknown. A systematic review of acute encephalitis in non-outbreak situations. Neurology. 2010;75(10):924-32.
2. Dubey D, Pittock SJ, Kelly CR, McKeon A, Lopez-Chiriboga AS, Lennon VA, et al. Autoimmune encephalitis epidemiology and a comparison to infectious encephalitis. Ann Neurol. 2018;83(1):166-77.

3. Darnell RB, Posner JB. Paraneoplastic syndromes involving the nervous system. N Engl J Med. 2003;349(16):1543-54.

4. Dalmau J, Rosenfeld MR. Paraneoplastic syndromes of the CNS. Lancet Neurol. 2008;7(4):327-40.

5. Graus F, Titulaer MJ, Balu R, Benseler S, Bien CG, Cellucci T, et al. A clinical approach to diagnosis of autoimmune encephalitis. Lancet Neurol [Internet]. 2016;15(4):391-404.. [cited 2019 Apr 17] Available from: https://www.sciencedirect.com/science/article/ pii/S1474442215004019?via\%3Dihub.

6. Granerod J, Ambrose HE, Davies NW, Clewley JP, Walsh AL, Morgan D, et al. Causes of encephalitis and differences in their clinical presentations in England: a multicentre, population-based prospective study. Lancet Infect Dis. 2010;10(12):835-44.

7. George BP, Schneider EB, Venkatesan A. Encephalitis hospitalization rates and inpatient mortality in the United States, 2000-2010. PLoS One. 2014;9(9):e104169.

8. Rubin DB, Batra A, Vodopivec I, Vaitkevicius H. Autoimmune encephalitis in critical care: optimizing immunosuppression. Semin Respir Crit Care Med. 2017;38(6):807-20.

9. Gaspard N, Foreman BP, Alvarez V, Cabrera Kang C, Probasco JC, Jongeling AC, et al. New-onset refractory status epilepticus: etiology, clinical features, and outcome. Neurology. 2015;85(18):1604-13.

10. Yeshokumar AK, Gordon-Lipkin E, Arenivas A, Cohen J, Venkatesan A, Saylor D, et al. Neurobehavioral outcomes in autoimmune encephalitis. J Neuroimmunol. 2017;312:8-14.

11. Harutyunyan G, Hauer L, Dunser MW, Karamyan A, Moser T, Pikija S, et al. Autoimmune encephalitis at the neurological intensive care unit: etiologies, reasons for admission and survival. Neurocrit Care. 2017;27(1):82-9.

12. Harutyunyan G, Hauer L, Dunser MW, Moser T, Pikija S, Leitinger $\mathrm{M}$, et al. Risk factors for intensive care unit admission in patients with autoimmune encephalitis. Front Immunol. 2017;8:835.

13. Mittal MK, Rabinstein AA, Hocker SE, Pittock SJ, Wijdicks EFM, McKeon A. Autoimmune encephalitis in the ICU: analysis of phenotypes, serologic findings, and outcomes. Neurocrit Care. 2016;24(2):240-50.

14. Newman MP, Blum S, Wong RCW, Scott JG, Prain K, Wilson RJ, et al. Autoimmune encephalitis. Intern Med J. 2016;46(2):148-57.

15. Schubert J, Bramer D, Huttner HB, Gerner ST, Fuhrer H, Melzer N, et al. Management and prognostic markers in patients with autoimmune encephalitis requiring ICU treatment. Neurol Neuroimmunol Neuroinflammation. 2019;6(1):e514.

16. Schankin CJ, Kastele F, Gerdes LA, Winkler T, Csanadi E, Hogen $\mathrm{T}$, et al. New-onset headache in patients with autoimmune encephalitis is associated with anti-NMDA-receptor antibodies. Headache. 2016;56(6):995-1003.

17. Ma C, Wang C, Zhang Q, Lian Y. Emerging role of prodromal headache in patients with anti-N-methyl-D-aspartate receptor encephalitis. J Pain Res. 2019;12:519-26.

18. Thompson J, Bi M, Murchison AG, Makuch M, Bien CG, Chu $\mathrm{K}$, et al. The importance of early immunotherapy in patients with faciobrachial dystonic seizures. Brain. 2018;141(2):348-56.

19. van Sonderen A, Arino H, Petit-Pedrol M, Leypoldt F, Kortvelyessy $\mathrm{P}$, Wandinger K-P, et al. The clinical spectrum of Caspr2 antibodyassociated disease. Neurology. 2016;87(5):521-8.

20. Titulaer MJ, McCracken L, Gabilondo I, Armangue T, Glaser C, Iizuka T, et al. Treatment and prognostic factors for long-term outcome in patients with anti-NMDA receptor encephalitis: an observational cohort study. Lancet Neurol. 2013;12(2):157-65. 
21. Dalmau J, Lancaster E, Martinez-Hernandez E, Rosenfeld MR, Balice-Gordon R. Clinical experience and laboratory investigations in patients with anti-NMDAR encephalitis. Lancet Neurol. 2011;10(1):63-74.

22. Shimoyama Y, Umegaki O, Agui T, Kadono N, Minami T. AntiNMDA receptor encephalitis presenting as an acute psychotic episode misdiagnosed as dissociative disorder: a case report. JA Clin Reps. 2016;2(1):22.

23. Chang Y, Kuo Y-H, Wu P-C, Yeh Y-C, Chen H-C. The misdiagnosis of steroid-responsive encephalopathy associated with autoimmune thyroiditis as masked depression in an elderly euthyroid woman. Psychosomatics. 2013;54(6):599-603.

24. Lilleker JB, Jones MS, Mohanraj R, Yeo T, Chai JYH, Tan K, et al. The relevance of VGKC positivity in the absence of LGI1 and Caspr2 antibodies. Neurology. 2016;87(17):1848-9.

25. Arino H, Armangue T, Petit-Pedrol M, Sabater L, MartinezHernandez E, Hara M, et al. Anti-LGI1-associated cognitive impairment: presentation and long-term outcome. Neurology. 2016;87(8):759-65.

26. Irani SR, Michell AW, Lang B, Pettingill P, Waters P, Johnson MR, et al. Faciobrachial dystonic seizures precede Lgil antibody limbic encephalitis. Ann Neurol. 2011;69(5):892-900.

27. McKeon A, Pittock SJ. Paraneoplastic encephalomyelopathies: pathology and mechanisms. Acta Neuropathol. 2011;122(4):381-400.

28. Schmitt SE, Pargeon K, Frechette ES, Hirsch LJ, Dalmau J, Friedman D. Extreme delta brush: a unique EEG pattern in adults with antiNMDA receptor encephalitis. Neurology. 2012;79(11):1094-100.

29. Gable M, Glaser C. Anti-N-methyl-D-aspartate receptor encephalitis appearing as a new-onset psychosis: disease course in children and adolescents within the California encephalitis project. Pediatr Neurol. 2017;72:25-30.

30. de Montmollin E, Demeret S, Brule N, Conrad M, Dailler F, Lerolle $\mathrm{N}$, et al. Anti-N-methyl-d-aspartate receptor encephalitis in adult patients requiring intensive care. Am J Respir Crit Care Med. 2017;195(4):491-9.

31. Spatola M, Petit-Pedrol M, Simabukuro MM, Armangue T, Castro FJ, Barcelo Artigues MI, et al. Investigations in GABAA receptor antibody-associated encephalitis. Neurology. 2017;88(11):1012-20.

32. Heine J, Pruss H, Bartsch T, Ploner CJ, Paul F, Finke C. Imaging of autoimmune encephalitis-relevance for clinical practice and hippocampal function. Neuroscience. 2015;309:68-83.

33. Vitaliani R, Mason W, Ances B, Zwerdling T, Jiang Z, Dalmau J. Paraneoplastic encephalitis, psychiatric symptoms, and hypoventilation in ovarian teratoma. Ann Neurol. 2005;58(4): 594-604.

34. Probasco JC, Solnes L, Nalluri A, Cohen J, Jones KM, Zan E, et al. Abnormal brain metabolism on FDG-PET/CT is a common early finding in autoimmune encephalitis. Neurol Neuroimmunol Neuroinflammation. 2017;4(4):e352.

35. Probasco JC, Solnes L, Nalluri A, Cohen J, Jones KM, Zan E, et al. Decreased occipital lobe metabolism by FDG-PET/CT: an antiNMDA receptor encephalitis biomarker. Neurol Neuroimmunol Neuroinflammation. 2018;5(1):e413.

36. Brown RKJ, Bohnen NI, Wong KK, Minoshima S, Frey KA. Brain PET in suspected dementia: patterns of altered FDG metabolism. Radiographics. 2014;34(3):684-701.

37. Fulham MJ, Brunetti A, Aloj L, Raman R, Dwyer AJ, Di Chiro G. Decreased cerebral glucose metabolism in patients with brain tumors: an effect of corticosteroids. J Neurosurg. 1995;83(4):657-64.

38. Matheja P, Weckesser M, Debus O, Lottgen J, Schuierer G, Schober $\mathrm{O}$, et al. Drug-induced changes in cerebral glucose consumption in bifrontal epilepsy. Epilepsia. 2000;41(5):588-93.
39. Singh TD, Fugate JE, Rabinstein AA. The spectrum of acute encephalitis: causes, management, and predictors of outcome. Neurology. 2015;84(4):359-66.

40. Inuzuka T. [Paraneoplastic neurological syndrome--definition and history]. Brain Nerve. 2010;62(4):301-8.

41. Pignolet BS, Gebauer CM, Liblau RS. Immunopathogenesis of paraneoplastic neurological syndromes associated with anti-Hu antibodies: a beneficial antitumor immune response going awry. Oncoimmunology (United States). 2013;2:e27384.

42. Vincent A, Bien CG, Irani SR, Waters P. Autoantibodies associated with diseases of the CNS: new developments and future challenges. Lancet Neurol. 2011;10(8):759-72.

43. Venkatesan A, Tunkel AR, Bloch KC, Lauring AS, Sejvar J, Bitnun A, et al. Case definitions, diagnostic algorithms, and priorities in encephalitis: consensus statement of the international encephalitis consortium. Clin Infect Dis. 2013;57(8):1114-28.

44. Venkatesan A, Michael BD, Probasco JC, Geocadin RG, Solomon T. Acute encephalitis in immunocompetent adults. Lancet (London England). 2019;393(10172):702-16.

45. Broadley J, Seneviratne U, Beech P, Buzzard K, Butzkueven H, O'Brien T, et al. Prognosticating autoimmune encephalitis: a systematic review. J Autoimmun. 2019;96:24-34.

46. McKeon A. Paraneoplastic and other autoimmune disorders of the central nervous system. Neurohospitalist. 2013;3(2):53-64.

47. Didelot A, Honnorat J. Paraneoplastic disorders of the central and peripheral nervous systems. Handb Clin Neurol. 2014;121:1159-79.

48. Lancaster $\mathrm{E}$. The diagnosis and treatment of autoimmune encephalitis. J Clin Neurol. 2016;12(1):1-13.

49. Szczeklik W, Wawrzycka K, Wludarczyk A, Sega A, Nowak I, Seczynska B, et al. Complications in patients treated with plasmapheresis in the intensive care unit. Anaesthesiol Intensive Ther. 2013;45(1):7-13.

50. Orbach H, Katz U, Sherer Y, Shoenfeld Y. Intravenous immunoglobulin: adverse effects and safe administration. Clin Rev Allergy Immunol. 2005;29(3):173-84.

51. Ehrlich S, Fassbender CM, Blaes C, Finke C, Gunther A, Harms L, et al. [Therapeutic apheresis for autoimmune encephalitis: a nationwide data collection]. Nervenarzt. 2013;84(4):498-507.

52. Jaben EA, Winters JL. Plasma exchange as a therapeutic option in patients with neurologic symptoms due to antibodies to voltagegated potassium channels: a report of five cases and review of the literature. J Clin Apher. 2012;27(5):267-73.

53. Fassbender C, Klingel R, Kohler W. Immunoadsorption for autoimmune encephalitis. Atheroscler Suppl. 2017;30:257-63.

54. Lee W-J, Lee S-T, Byun J-I, Sunwoo J-S, Kim T-J, Lim J-A, et al. Rituximab treatment for autoimmune limbic encephalitis in an institutional cohort. Neurology. 2016;86(18):1683-91.

55. Byun J-I, Lee S-T, Jung K-H, Sunwoo J-S, Moon J, Lim J-A, et al. Effect of immunotherapy on seizure outcome in patients with autoimmune encephalitis: a prospective observational registry study. PLoS One. 2016;11(1):e0146455.

56. Leroy C, Rigot J-M, Leroy M, Decanter C, Le Mapihan K, Parent A-S, et al. Immunosuppressive drugs and fertility. Orphanet J Rare Dis. 2015;10:136.

57. Davies G, Irani SR, Coltart C, Ingle G, Amin Y, Taylor C, et al. Anti-N-methyl-D-aspartate receptor antibodies: a potentially treatable cause of encephalitis in the intensive care unit. Crit Care Med. 2010;38(2):679-82.

58. Chi X, Wang W, Huang C, Wu M, Zhang L, Li J, et al. Risk factors for mortality in patients with anti-NMDA receptor encephalitis. Acta Neurol Scand. 2017;136(4):298-304.

59. Pandit AK, Ihtisham K, Garg A, Gulati S, Padma MV, Tripathi M. Autoimmune encephalitis: a potentially reversible cause of status epilepticus, epilepsy, and cognitive decline. Ann Indian Acad Neurol. 2013;16(4):577-84. 
60. de Bruijn MAAM, van Sonderen A, van Coevorden-Hameete MH, Bastiaansen AEM, Schreurs MWJ, Rouhl RPW, et al. Evaluation of seizure treatment in anti-LGI1, anti-NMDAR, and anti-GABABR encephalitis. Neurology. 2019;92(19):e2185-96.

61. Lopinto-Khoury C, Sperling MR. Autoimmune status epilepticus. Curr Treat Options Neurol. 2013;15(5):545-56.

62. Cikrikcili U, Ulusoy C, Turan S, Yildiz S, Bilgic B, Hanagasi H, et al. Non-convulsive status epilepticus associated with glutamic acid decarboxylase antibody. Clin EEG Neurosci. 2013;44(3):232-6.

63. Thakur KT, Probasco JC, Hocker SE, Roehl K, Henry B, Kossoff $\mathrm{EH}$, et al. Ketogenic diet for adults in super-refractory status epilepticus. Neurology. 2014;82(8):665-70.

64. Cervenka MC, Hocker S, Koenig M, Bar B, Henry-Barron B, Kossoff $\mathrm{EH}$, et al. Phase I/II multicenter ketogenic diet study for adult superrefractory status epilepticus. Neurology. 2017;88(10):938-43.

65. Wang Y, Zhang W, Yin J, Lu Q, Yin F, He F, et al. Anti-N-methyl-Daspartate receptor encephalitis in children of central South China: clinical features, treatment, influencing factors, and outcomes. J Neuroimmunol. 2017;312:59-65.

66. Mehr SR, Neeley RC, Wiley M, Kumar AB. Profound autonomic instability complicated by multiple episodes of cardiac asystole and refractory bradycardia in a patient with anti-NMDA encephalitis. Case Rep Neurol Med. 2016;2016:7967526.

67. Venkatesan A, Geocadin RG. Diagnosis and management of acute encephalitis: a practical approach. Neurol Clin Pract. 2014;4(3):206-15.

68. Hoftberger R, van Sonderen A, Leypoldt F, Houghton D, Geschwind M, Gelfand J, et al. Encephalitis and AMPA receptor antibodies: novel findings in a case series of 22 patients. Neurology. 2015;84(24):2403-12.

69. Pittock SJ, Lucchinetti CF, Parisi JE, Benarroch EE, Mokri B, Stephan CL, et al. Amphiphysin autoimmunity: paraneoplastic accompaniments. Ann Neurol. 2005;58(1):96-107.

70. Honnorat J, Cartalat-Carel S, Ricard D, Camdessanche JP, Carpentier AF, Rogemond V, et al. Onco-neural antibodies and tumour type determine survival and neurological symptoms in paraneoplastic neurological syndromes with $\mathrm{Hu}$ or CV2/CRMP5 antibodies. J Neurol Neurosurg Psychiatry. 2009;80(4):412-6.

71. Vernino S, Tuite P, Adler CH, Meschia JF, Boeve BF, Boasberg P, et al. Paraneoplastic chorea associated with CRMP-5 neuronal antibody and lung carcinoma. Ann Neurol. 2002;51(5):625-30.

72. Vigliani MC, Honnorat J, Antoine J-C, Vitaliani R, Giometto B, Psimaras D, et al. Chorea and related movement disorders of paraneoplastic origin: the PNS EuroNetwork experience. J Neurol. 2011;258(11):2058-68.

73. Hoftberger R, Titulaer MJ, Sabater L, Dome B, Rozsas A, Hegedus B, et al. Encephalitis and GABAB receptor antibodies: novel findings in a new case series of 20 patients. Neurology. 2013;81(17):1500-6.

74. McKeon A, Tracy JA. GAD65 neurological autoimmunity. Muscle Nerve. 2017;56(1):15-27.

75. Graus F, Keime-Guibert F, Rene R, Benyahia B, Ribalta T, Ascaso $\mathrm{C}$, et al. Anti-Hu-associated paraneoplastic encephalomyelitis: analysis of 200 patients. Brain. 2001;124(Pt 6):1138-48.

76. Ortega Suero G, Sola-Valls N, Escudero D, Saiz A, Graus F. Anti-Ma and anti-Ma2-associated paraneoplastic neurological syndromes. Neurologia. 2018;33(1):18-27.
77. Jarius S, Ruprecht K, Kleiter I, Borisow N, Asgari N, Pitarokoili K, et al. MOG-IgG in NMO and related disorders: a multicenter study of 50 patients. Part 2: Epidemiology, clinical presentation, radiological and laboratory features, treatment responses, and long-term outcome. J Neuroinflammation. 2016;13(1):280.

78. Sato DK, Callegaro D, Lana-Peixoto MA, Waters PJ, de Haidar Jorge FM, Takahashi T, et al. Distinction between MOG antibodypositive and AQP4 antibody-positive NMO spectrum disorders. Neurology. 2014;82(6):474-81.

79. Dale RC, Merheb V, Pillai S, Wang D, Cantrill L, Murphy TK, et al. Antibodies to surface dopamine-2 receptor in autoimmune movement and psychiatric disorders. Brain. 2012;135(Pt 11):3453-68.

80. McKeon A, Lennon VA, Lotze T, Tenenbaum S, Ness JM, Rensel $\mathrm{M}$, et al. CNS aquaporin-4 autoimmunity in children. Neurology. 2008;71(2):93-100.

81. Hara M, Arino H, Petit-Pedrol M, Sabater L, Titulaer MJ, MartinezHernandez E, et al. DPPX antibody-associated encephalitis: Main syndrome and antibody effects. Neurology. 2017;88(14):1340-8.

82. Spatola M, Sabater L, Planaguma J, Martinez-Hernandez E, Armangue T, Pruss H, et al. Encephalitis with mGluR5 antibodies: symptoms and antibody effects. Neurology. 2018;90(22): e1964-72.

83. Titulaer MJ, McCracken L, Gabilondo I, Iizuka T, Kawachi I, Bataller L, et al. Late-onset anti-NMDA receptor encephalitis. Neurology. 2013;81(12):1058-63.

84. de Bruijn MAAM, Aarsen FK, van Oosterhout MP, van der Knoop MM, Catsman-Berrevoets CE, Schreurs MWJ, et al. Long-term neuropsychological outcome following pediatric anti-NMDAR encephalitis. Neurology. 2018;90(22):e1997-2005.

85. Ho AC-C, Chan SH-S, Chan E, Wong SS-N, Fung ST-H, Cherk SW-W, et al. Anti-N-methyl-D-aspartate receptor encephalitis in children: incidence and experience in Hong Kong. Brain and Development. 2018;40(6):473-9.

86. Granata T, Matricardi S, Ragona F, Freri E, Zibordi F, Andreetta F, et al. Pediatric NMDAR encephalitis: a single center observation study with a closer look at movement disorders. Eur J Paediatr Neurol. 2018;22(2):301-7.

87. Zhang L, Liu X, Jiang X-Y, Wang Y-H, Li J-M, Zhou D. Late-onset anti-N-methyl-D-aspartate receptor encephalitis in China. Epilepsy Behav. 2018;84:22-8.

88. Mueller SH, Farber A, Pruss H, Melzer N, Golombeck KS, Kumpfel $\mathrm{T}$, et al. Genetic predisposition in anti-LGI1 and anti-NMDA receptor encephalitis. Ann Neurol. 2018;83(4):863-9.

89. Finke C, Pruss H, Heine J, Reuter S, Kopp UA, Wegner F, et al. Evaluation of cognitive deficits and structural hippocampal damage in encephalitis with leucine-rich, glioma-inactivated 1 antibodies. JAMA Neurol. 2017;74(1):50-9.

90. Gao L, Liu A, Zhan S, Wang L, Li L, Guan L, et al. Clinical characterization of autoimmune LGI1 antibody limbic encephalitis. Epilepsy Behav. 2016;56:165-9.

91. Celicanin M, Blaabjerg M, Maersk-Moller C, Beniczky S, Marner L, Thomsen C, et al. Autoimmune encephalitis associated with voltage-gated potassium channels-complex and leucine-rich glioma-inactivated 1 antibodies - a national cohort study. Eur J Neurol. 2017;24(8):999-1005 